\title{
DEVELOPMENT OF MAGAZINE AS A LEARNING MEDIA ON ENDOCRINE SYSTEM
}

\author{
Putri Anggraini ${ }^{1}$, Ruqiah Ganda Putri Panjaitan ${ }^{2}$, Eko Sri Wahyuni ${ }^{3}$ \\ 1,2,3 Program Studi Pendidikan Biologi, Fakultas Keguruan dan Ilmu Pendidikan, Universitas Tanjungpura \\ Pontianak, 78124, Indonesia \\ putrianggraini198@gmail.com
}

Accepted: October 28, 2021

Published: October 31, 2021

DOI: https://doi.org/10.21107/jps.v8i2.10433

\begin{abstract}
The magazine is one of the learning media that is rarely used in school. This research aimed to know the feasibility of endocrine system magazines and examine the learners' response to magazines as the media. This type of research is research and development. Five expert judgments tested the feasibility of the magazine. The aspects that were assessed were the material and media aspects. The product trials were done on nine students - the responses measured included cognitive, affective, and conative. The result of this research showed, on the feasible test CVR score of the material and media aspects was 1. Moreover, the CVI score was one as well. On the product trial, the score for cognitive aspect 85,18\%, affective 83,33\%, conative $87,77 \%$, and the average responses $85,42 \%$. It can be concluded that endocrine system magazine was feasible as learning media. Furthermore, magazines as a media gained a positive and strong response. So magazines can be a choice of media that can help learning activities.
\end{abstract}

Keywords: Magazine, Students' responses, Validity

\footnotetext{
${ }^{1}$ Corresponding Author
} 


\section{Introduction}

In essence, learning is an activity designed so that a person can learn well. This activity leads to obtaining behavioral changes by students and the delivery of learning materials by teachers (Pane \& Dasopang, 2017). Various elements influence a compelling, engaging, and fun learning process for students, including teachers understanding the characteristics of students, choosing studentcentered learning methods, adequate learning facilities, the availability of various learning resources, and the use of exciting media. (Budiman, 2016).

Learning media is one of the essential components whose use is a must for teachers (Putri $\&$ Citra, 2019). Teachers are required to use media and be creative in developing learning media (Pito, 2018). However, many teachers still do not apply innovative learning media or do not even use learning media so that learning becomes monotonous and students feel bored (Tafonao, 2018). In addition, the use of conventional and instant media makes it possible that the media is not contextual, less attractive, monotonous, and does not follow the needs of students (Saputro \& Suharto, 2015). Based on the results of interviews conducted with three high school biology teachers in Pontianak regarding the use of learning media on the endocrine system material, it is known that teachers in school A use PowerPoint (PPT), teachers in school B use pictures, and teachers in school $\mathrm{C}$ do not use learning media in teaching the material on the endocrine system.

Learning media contribute to conveying educative messages from teachers to students to learn effectively and efficiently (Wahyuliana, Supriadi, \& Anwar, 2016). Learning media helps the teacher's role and creates an active, innovative, creative, and fun learning atmosphere (Supriyono, 2018). Learning media makes abstract concepts concrete (Supriyono, 2018; Wulandari, Ruhiat, \& Nulhakim, 2020). In addition, learning media provides the same experience for students regarding events in their environment (Hamka \& Effendi, 2019).

Magazines are print media that contain content and images packaged attractively and simply intending to make it easier to understand the concept (Pratiwi, Gardjito, Hamidah, 2017). The contents of the magazine can be in the form of rubrics with certain concepts. In addition, the magazine also contains quizzes and crosswords (Zahro \& Astono, 2017). Magazines can help understand biological material and provide fun in learning biology (Dewi \& Warso, 2014). Magazine displays filled with text and images that are varied and colorful can attract many people to read them. Magazine display gives the impression of being relaxed and not dull so that it is considered more attractive (Najihah \& Sanjaya, 2014).

Zahro \& Astono (2017) stated that magazines could increase students' motivation and learning of physics. In addition, Pratiwi et al. (2017) conveyed the results of a small group trial on a protist material biology magazine, which resulted in a good response. However, the use of magazines as learning media is still rarely used in schools.

Magazines can be a variation or choice of learning media, especially on endocrine system material. Magazines will facilitate students' learning by excitingly presenting the material. In addition, the insertion of additional information in the form of research results related to learning materials can add insight for students in studying endocrine system material. This study aimed to determine the feasibility of the endocrine system magazine media and test the students' responses to the use of magazine media.

\section{Research Methods}

The type of research used is research and development (research and development). The stages of this research refer to Sugiyono (2017), but only seven stages are carried out and are presented in Figure 1.

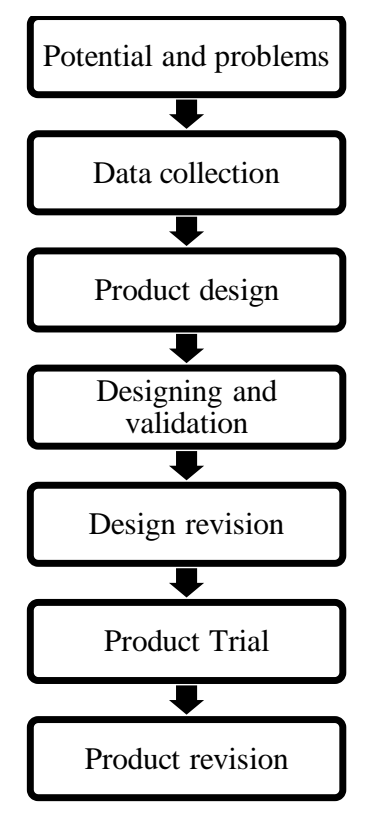

Figure 1. Research stages

The potential and problem stages are the importance of media in the learning process, and magazines can be used as an alternative to learning media. The data collection stage is related to 
collecting information about the learning media used by teachers in schools. The product design stage is the design of the endocrine system magazine media. The preparation of magazine media was adopted from Asfuriyah's research (2014) with the following stages: a) formulating essential competencies and objectives to be achieved, b) collecting article materials, c) determining evaluation tools, d) compiling articles, and e) magazine structure.

Magazine media was created using the Microsoft Publisher 2010 application and printed using Art Paper. The validation stage is carried out to determine the feasibility. The magazine was tested for feasibility by five validators consisting of 2 lecturers and three teachers. The feasibility of magazine media is reviewed based on media and material aspects (Nurhasanah, Denny, \& Utami, 2020).

The design revision stage is the design improvement based on the validator's suggestions. The validation data were analyzed using Content Validity Ratio (CVR) and Content Validity Index (CVI) analysis according to Lawshe (1975). The final calculation of CVR and CVI scores meets Lawshe's (1975) minimum limit value of 0.99 . Then the media is declared valid and feasible. The product trial phase is in the form of a limited trial conducted by giving response questionnaires to respondents. The measured responses are divided into three namely cognitive, affective and conative (Amir, 2017). The trial was conducted on nine students (Sukmadinata, 2012) who came from 3 schools. The criteria for interpreting the response questionnaire scores are presented in table 1 . The product revision stage is carried out if there are deficiencies in the magazine media based on the test results.

Table 1. Interpretation of Scores

\begin{tabular}{cc}
\hline Score & description \\
\hline $0 \%-20 \%$ & Very Weak \\
$21 \%-40 \%$ & Weak \\
$41 \%-60 \%$ & Moderat \\
$61 \%-80 \%$ & Strong \\
$81 \%-100 \%$ & Very Strong \\
\hline
\end{tabular}

(Riduwan, 2015)

\section{Result and Discussion}

The developed endocrine system sub-material magazine consists of the cover page, title page, introduction page, table of contents page, core competency page, basic competence and learning objectives, concept map page, a text page, glossary page, and bibliography page. Pages in the magazine media refer to Purnomowati (2003), modified by

\section{Development of Magazine As a Learning Media}

adding page types. The text page contains material exploration rubrics, research, let's try, scientist info, and brain teasers. The rubric was developed based on Asfuriyah (2014) research, which has been modified by differentiating the types of rubrics according to the magazine's theme. The magazine media display from this research is presented in Figure 2.

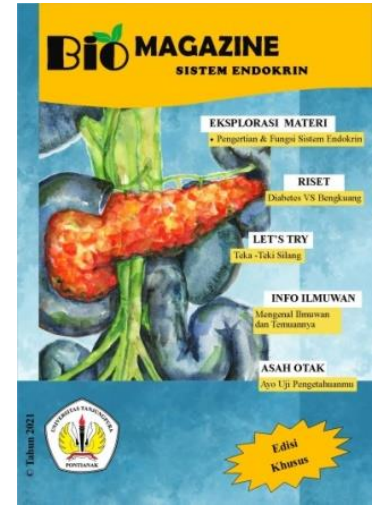

(a)

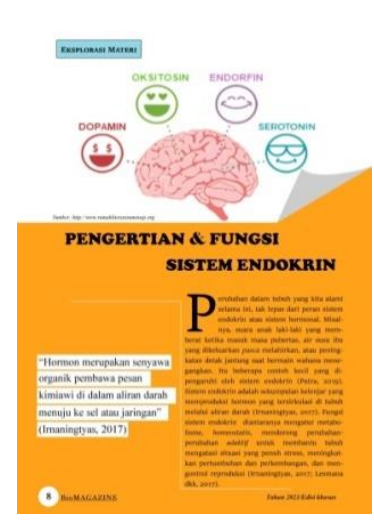

(c)

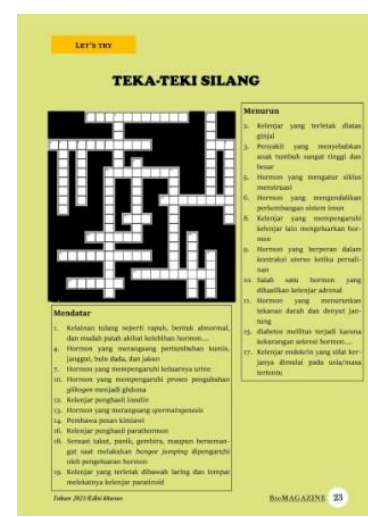

(e)

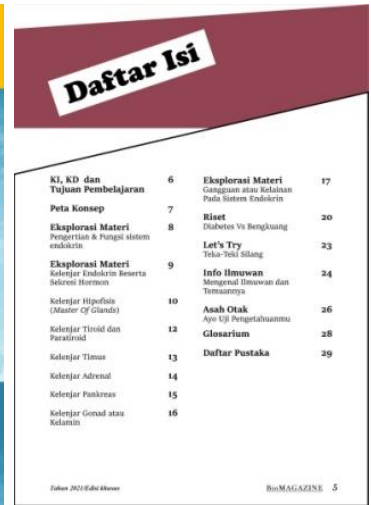

(b)

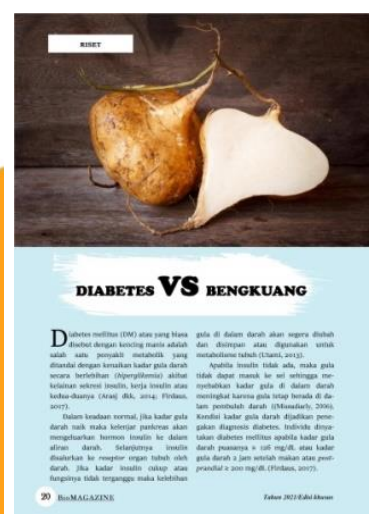

(d)

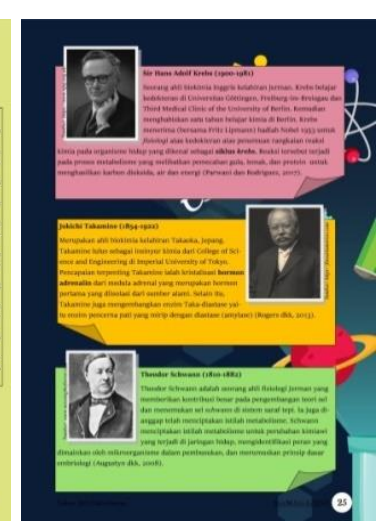

(f)
Figure 2. Display of several sections of magazine media, (a) Cover page, (b) table of contents, (c) material exploration rubric, (d) research rubric, (e) let's try rubric, and (f) scientist info rubric

Five validators' validation of the endocrine system sub-material magazine media that was carried out showed that the endocrine system submaterial magazine media was appropriate to be 


\section{Anggraini, Panjaitan, Wahyuni}

used as a learning medium both from the material and media aspects. It can be seen in table 2. that all validation indicators have CVR and CVI values exceeding the minimum CVR and CVI scores for five validators, according to Lawshe (1975), which is 0.99 .

Table 2. The Results of Validation of "Endocrine System Magazine"

\begin{tabular}{|c|c|c|c|}
\hline \multirow{2}{*}{$\begin{array}{r}\text { Item } \\
\text { Material }\end{array}$} & \multicolumn{2}{|c|}{ Indicator } & \multirow{2}{*}{$\begin{array}{c}\text { CVR } \\
1\end{array}$} \\
\hline & 1. Completeness & & \\
\hline & 2. Updating & & 1 \\
\hline & 3. Accuracy & & 1 \\
\hline & $\begin{array}{l}\text { 4. Application } \\
\text { Terms, and } \\
\text { names) }\end{array}$ & $\begin{array}{r}\text { (Symbols, } \\
\text { Scientific }\end{array}$ & 1 \\
\hline \multirow[t]{9}{*}{ Media } & 5. Appearance of 1 & agazine & 1 \\
\hline & $\begin{array}{l}\text { 6. Completeness } \\
\text { Compatibility o }\end{array}$ & Rubric ${ }^{\text {and }}$ & 1 \\
\hline & 7. Magazine Cove & & 1 \\
\hline & 8. Image Display & & 1 \\
\hline & 9. Layout & & 1 \\
\hline & 10. Language Accu & & 1 \\
\hline & 11. Readability & & 1 \\
\hline & 12. Typography & & 1 \\
\hline & CVI & & 1 \\
\hline
\end{tabular}

The media for the endocrine system magazine is prepared by referring to the syllabus for biology class XI high school curriculum 2013 as a learning medium. The magazine media contains the concept of the endocrine system, which includes the understanding and function of the endocrine system, the glands of the endocrine system and their secretion of hormones, and disorders or disorders of the endocrine system.

The validity of the endocrine system magazine was measured through 12 indicators. Panjaitan, Titin, \& Santoso (2019) stated that learning media must first be assessed for validity before being used in the learning process. Based on table 2 shows that all validity indicators get a CVR value of 1 . Likewise, the CVI value, magazine media gets a value of 1 . So it can be stated that the endocrine system magazine media is suitable for use as learning media.

The material aspect consists of 4 indicators: the completeness of the material, the updating of the material, the accuracy of the material, and the use of terms, symbols, and scientific names. The results of the analysis show that the four indicators are declared valid. The first indicator, the completeness of the material, obtained a CVR value of 1 . It indicates that the material presented in the magazine media is complete. The indicator of material updates gets a CVR value of 1 , which means that the material in the magazine media is by the development of science. The accuracy indicator obtained a CVR value of 1 , indicating that the material presented is by the concept of biology. Sari (2019) said that one of the considerations in choosing media is the quality of the content or material. Quality material is viewed from the accuracy of the depth material presented and under the development and abilities of students. In addition, the material presented follows the learning objectives. The indicators for the use of terms, symbols, and scientific names were also declared valid because they obtained a CVR value of 1 . Consistency in terms, symbols, and scientific names make it easier for students to understand the magazine's contents and not confuse it.

The media aspect consists of 8 indicators: magazine appearance, completeness and suitability of the rubric, magazine cover, image display, layout, language accuracy, legibility, and typography. As with the material aspect, in the media aspect, all indicators are declared valid with a CVR value of 1 . That indicates that the magazine media is considered attractive. The display of the developed magazine is made in full color to attract readers. In line with Handini (2020), it states that bright colors create a cheerful atmosphere to foster students' interest and enthusiasm for learning.

The cover of the endocrine system magazine is designed in color and includes the rubrics discussed. The cover is also equipped with images related to the learning material. For a product, the cover describes the content of the media it represents and attracts attention. So it is essential to design a cover that fits the target reader (Arinda, 2016). In addition to the cover with pictures, the contents of the magazine are also equipped with pictures. According to Anantyarta \& Sholihah (2020), a display equipped with pictures can strengthen the explanation of the writing submitted. Arinda (2020) also revealed that images could concretize abstract concepts. It is undoubtedly in line with the function of learning media, namely making abstract concepts more concrete (Wulandari et al., 2020).

The layout of the magazine media is designed to make it easier for readers to read magazines. In addition, the layout element has unity. Anto, Andrijanto, \& Akbar (2017) said that the layout aims to make the design beautiful and attractive. The indicators of conformity to the use of language that are declared valid indicate that the 
grammar used in the magazine media follows PUEBI and the development of students, straightforward and clear. Readability indicators include the ease of understanding the contents of the magazine's text. Fatin (2017) argues that readability is related to sentence structure. If the reading is formed with a sentence structure that is not good, then the content will be complex for the reader to understand. Difficult reading will cause students to be frustrated and not interested in reading.

In the typography indicator, selecting the type of font used in the magazine media is not excessive, and the font size is adjusted to the needs. In addition, the selection of font colors does not vary intended so that the font contrasts with the background and does not interfere with the view when reading it. Anton et al. (2017) argue that typography acts as a messenger to be communicated in the most precise and most legible form.

The results of the CVI calculation for magazine media obtained a value of 1 (table 2). The CVI value illustrates that all parts of the magazine follow the established indicators so that the magazine media is declared suitable for use as a learning medium on endocrine system material.

Product trials on the use of magazine media are known to have the highest average value shown in the conative aspect of $87.77 \%$, followed by cognitive at $85.18 \%$, and affective at $83.33 \%$. Based on the score interpretation criteria, the students' responses were categorized as very strong, both cognitive, affective, and conative. The results of product trials are presented in table 3.

Table 3. Results of questionnaire analysis of student responses to magazine media

\begin{tabular}{|c|c|c|c|}
\hline Item & Indicator & $\begin{array}{c}\text { Score } \\
(\%)\end{array}$ & $\begin{array}{c}\text { Average } \\
(\%)\end{array}$ \\
\hline \multirow[t]{3}{*}{ Cognitive } & $\begin{array}{l}\text { 1. students' } \\
\text { understanding of the } \\
\text { contents }\end{array}$ & 85,55 & \multirow{3}{*}{85,18} \\
\hline & $\begin{array}{l}\text { 2. students' perceptions } \\
\text { of the appearance }\end{array}$ & 85,55 & \\
\hline & $\begin{array}{l}\text { 3. students' perceptions } \\
\text { of the questions }\end{array}$ & 84,45 & \\
\hline \multirow[t]{2}{*}{ Afektif } & 4. students' interest & 82,22 & \multirow[b]{2}{*}{83,335} \\
\hline & 5. Students' curiosity & $\begin{array}{c}84,45 \\
\%\end{array}$ & \\
\hline Conative & $\begin{array}{l}\text { 6. tendency to apply it } \\
\text { in everyday life }\end{array}$ & $\begin{array}{c}87,77 \\
\%\end{array}$ & $87,77 \%$ \\
\hline & Average Responses & & $85,42 \%$ \\
\hline
\end{tabular}

Student responses were measured using a questionnaire involving three aspects, namely cognitive, affective, and conative. This questionnaire consists of 6 indicators and 12 statements. The responses given are in the form of positive and negative responses. The analysis results (Table 3) show a positive and very strong response with an average response percentage of $85.42 \%$.

The cognitive aspect obtained an average score of $85.18 \%$, with a very strong category. This aspect consists of 3 indicators: the convenience of understanding the contents of the endocrine system magazine, students' perceptions of the appearance of the endocrine system magazines, and students' perceptions of the questions presented. On the indicator of ease of understanding the contents of the endocrine system magazine, the percentage score is $85.55 \%$. It shows that the language used in the magazine is communicative, making it easier for students to understand the magazine's contents. The indicator of students' perception of the appearance of the endocrine system magazine scored $85.55 \%$. Magazines are displayed with matching images and matching color combinations. The use of animation, video, and images in learning media contributes to making learning more exciting and supports the learning process, so that good learning outcomes are obtained (Soimah, 2018). In addition, the use of color has a positive impact because it can improve students' memory skills (Sujarwo \& Oktaviana, 2017). Then the indicator of students' perceptions of the questions presented obtained a value of $84.45 \%$. The practice questions aim to determine the level of students' understanding of the material being studied (Anantyarta \& Sholihah, 2020; Handini, 2020).

The affective aspect is categorized as very strong, with an average value percentage of $83.33 \%$. This aspect consists of 2 indicators, namely students' interest in endocrine system magazines and curiosity. The indicator of students' interest in the endocrine system magazine scored $82.22 \%$. It shows that students are interested in learning to use magazine media. Subroto, Qohar, \& Dwiyana (2020) stated that images and page color variations could attract students. So it can be seen that students are more interested in media equipped with images and various colors. The curiosity indicator scored $84.45 \%$. It indicates that the magazine media can arouse curiosity by providing information about the research result on the antidiabetic activity of yam tuber extract.

The conative aspect was also categorized as very strong and obtained a percentage of $87.77 \%$, in this aspect, namely the tendency to apply it in everyday life. It shows that information about disorders or abnormalities in the endocrine system 


\section{Anggraini, Panjaitan, Wahyuni}

raises the desire of students to implement a healthy lifestyle to maintain the health of endocrine organs.

The magazine is made as attractive as possible with a colorful display and is equipped with pictures. It aims to give a relaxed impression. In addition, this magazine contains additional information in the form of a rubric on the results of research on the antidiabetic activity of yam tuber extract, which is relevant to the material on the endocrine system so that students can understand the workings of endocrine organs and link the functions of endocrine organs and the role of plants that affect endocrine organs.

\section{Conclusion}

From this research, it can be concluded that the endocrine system magazine is considered suitable for use as a learning medium. In addition, product trials on the use of endocrine system magazines received a positive and very strong response.

\section{References}

Amir, M. T. (2017). Merancang Kuesioner: Konsep dan Panduan untuk Penelitian Sikap, Kepribadian, dan Perilaku. Jakarta: Kencana.

Anto, P., Andrijanto, M. S., \& Akbar, T. (2017). Perancangan Buku Pedoman Umum Ejaan Bahasa Indonesia sebagai Media Pembelajaran Ejaan di Sekolah. Jurnal Desain, 4(2), 92-99. DOI: http://dx.doi.org/10.30998/jurnaldesa in.v4i02.1131.

Anantyarta, P., \& Sholihah, F. N. (2020). Pengembangan Multimedia Pembelajaran pada Bioteknologi menggunakan Program Autoplay. Journal of Science and Integration, 3(1), 45-57. DOI: http://dx.doi.org/10.24014/jnsi.v3i1.9 036.

Arinda, F. D. (2016). Pengembangan Multimedia Pembelajaran Interaktif Ilmu Pengetahuan Sosial SMP. Jurnal Inovasi dan Teknologi Pembelajaran, 1(4), 302-306.

DOI: http://dx.doi.org/10.17977/um031v2i2201 $6 \mathrm{p} 302$.

Asfuriyah, S. (2014). Pengembangan Majalah Sains Berbasis Contextual Learning Sebagai Media Pembelajaran IPA Tema
Pemanasan Global untuk SMP. Skripsi. Universitas Negeri Semarang.

Budiman, H. (2016). Penggunaan Media Visual dalam Proses Pembelajaran. $A l$ Tadzkiyyah: Jurnal Pendidikan Islam, 7(2), 171-182.

DOI: https://doi.org/10.24042/atjpi.v7i2.15 01 .

Dewi, N. A., \& Warso, A. W. D. D. (2014). Pengembangan Majalah Green Sebagai Media Pembelajaran Biologi pada Materi Sistem Reproduksi Manusia untuk Siswa Kelas XI IPA SMA. JUPEMASI-PBIO, 1(1), 155- $157 . \quad$ Retrieved from http://jupemasipbio.uad.ac.id.

Fatin, I. (2017). Keterbacaan Buku Teks Bahasa Indonesia Kelas X Kurikulum 2013 Edisi Revisi 2016 dengan Formula Fry. Jurnal Ilmiah Program Studi Pendidikan Bahasa \& Sastra, 2(1), 21-33. DOI: https://doi.org/10.32528/bb.v2i1.643.

Handini, A. (2020). Pengembangan Video Pembelajaran Membaca Teks Berita bagi Siswa SMP Kelas VIII. BASINDO: Jurnal Kajian Bahasa, Sastra Indonesia, dan Pembelajaran, 4(2), 233-241. Retrieved from

http://journal2.um.ac.id/index.php/basindo/ article/view/8387.

Hamka, D., \& Effendi, N. (2019). Pengembangan Media Pembelajaran Blended Learning Berbasis Edmodo pada Mata Kuliah Fisika Dasar di Program Studi Pendidikan IPA. Journal of Science and Integration, 2(1), 19-33.

DOI: http://dx.doi.org/10.24014/jnsi.v2i1.7 111.

Lawshe, C. H.. (1975). A Quantitive Approach to Content Validity. Purdue University: Personnel Psychology, Inc.

Najihah, S., \& Sanjaya, I. G. M. (2014). Pengembangan Model E-Book Interaktif Termodifikasi Majalah Pada Materi Struktur Atom. Unesa Journal of Chemical Education, 3(3), 100-104. Retrieved from https://jurnalmahasiswa.unesa.ac.id.

Nurhasanah, N., Denny, Y. R., \& Utami, I. S. (2020). Penerapan Media Pembelajaran Majalah Fisika "Physicsmagz" Berbasis 
Contextual Learning Untuk

Meningkatakan Kemampuan Literasi

Sains. SPEKTRA: Jurnal Kajian

Pendidikan Sains, 6(1), 53-63.

DOI:http://dx.doi.org/10.32699/spektra.v6

vili.129.

Pane, A., \& Dasopang, M. D. Belajar dan Pembelajaran. FITRAH Jurnal Kajian Ilmu-Ilmu Keislaman, 3(2), 333-352. Retrieved from http://jurnal.iainpadangsidimpuan.ac.id.

Panjaitan, R.G. P., Titin., \& Santoso, R. (2019). Film Dokumenter Pemanfaatan Tumbuhan Berkhasiat Obat sebagai Media Pembelajaran Materi Sistem Pencernaan. Jurnal Pendidikan Sains Indonesia, 7(2): 121-131.

DOI: https://doi.org/10.24815/jpsi.v7i2.14 808.

Pito, A. H. (2018). Media Pembelajaran dalam Perspektif Alquran. Andragogi Jurnal Diklat Teknis, 6(2), 97- 117. Retrieved from https://media.neliti.com.

Pratiwi, N., Gardjito., \& Hamidah, A. (2017). Pengembangan Majalah Biologi sebagai Media Pembelajaran Pada Pokok Bahasan Protista Kelas X MIA di SMA N 7 Kota Jambi. Jurnal Biodik, 3(1), 27-34. DOI: https://doi.org/10.22437/bio.v3i1.488 0

Purnomowati, S. (2003). Penampilan Majalah Ilmiah: Standar dan Penerapannya. Jurnal Dokumentasi dan Informasi, 27(1), 20-27.

DOI: https://doi.org/10.14203/j.baca.v27i1.68.

Putri, S. D., \& Citra, D. E. (2019). Problematika Guru dalam Menggunakan Media Pembelajaran pada Mata Pelajaran IPS di Madrasah Ibtidaiyah Darussalam Kota Bengkulu. Indonesia Journal of Social Science Education, 1(1), 49-54. DOI: http://dx.doi.org/10.29300/ijsse.v1i1. 1325.

Riduwan. (2015). Dasar - Dasar Statistika. Bandung: Penerbit Alfabeta.

Saputro, H. B., \& Soeharto. (2015). Pengembangan Media Komik Berbasis Pendidikan Karakter pada Pembelajaran TematikIntegratif Kelas IV SD. Jurnal Prima Edukasia, $\quad 3(1), \quad$ 61-72.
DOI: https://doi.org/10.21831/jpe.v3i1.406 5.

Sari, P. (2019). Analisis terhadap Kerucut Pengalaman Edgar Dale dan Keragaman Gaya Belajar untuk Memilih Media yang Tepat dalam Pembelajaran. Mudir: Jurnal Manajemen Pendidikan, 1(1), 58-78. DOI: https://doi.org/10.36835/mudir.v1i1. 27

Soimah, I. (2018). Pengaruh Media Pembelajaran Berbasis Komputer terhadap Hasil Belajar IPA Ditinjau dari Motivasi Belajar Siswa. NATURAL: Jurnal Ilmiah Pendidikan IPA, 5(1)38-44.

DOI: http://dx.doi.org/10.30738/natural.v5 i1.2559.

Subroto, E. E., Qohar, A., \& Dwiyana. (2020). Efektivitas Pemanfaatan Komik sebagai Media Pembelajaran Matematika. Jurnal Pendidikan: Teori, Penelitian, dan Pengembangan, 5(2), 135-141. DOI: http://dx.doi.org/10.17977/jptpp.v5i2 .13156 .

Sujarwo, S., \& Oktaviana, R. (2017). Pengaruh Warna Terhadap Short Term Memory pada Siswa Kelas VIII SMP N 37 Palembang. PSIKIS-Jurnal Psikologi Islami, 3(1), 3342.

DOI: https://doi.org/10.19109/psikis.v3i1.1 391.

Sukmadinata, N. S. (2012). Metode Penelitian Pendidikan. Bandung: PT Remaja Rosdakarya.

Sugiyono. (2017). Metode Penelitian Pendidikan. Bandung: Penerbit Alfabeta.

Supriyono. (2018). Pentingnya Media Pembelajaran untuk Meningkatkan Minat Belajar Siswa SD. Edustream: Jurnal Pendidikan Dasar, 2(1), 43-48. Retrieved from https://journal.unesa.ac.id/.

Tafonao, T. (2018). Peranan Media Pembelajaran dalam Meningkatkan Minat Belajar Mahasiswa. Jurnal Komunikasi Pendidikan, 2(2), 103-114. DOI: https://doi.org/10.32585/jkp.v2i2.113

Wahyuliana, Y., Supriadi, U., dan Anwar, S. (2016). Efektivitas Penggunaan Media 


\section{Anggraini, Panjaitan, Wahyuni}

Pembelajaran Flip Book Terhadap Peningkatan Hasil Belajar Siswa Pada Mata Pelajaran PAI dan Budi Pekerti di SMA Negeri 4 Bandung. TARBAWY, 3(1), 22-36.

DOI: https://doi.org/10.17509/t.v3i1.3457.

Wulandari, Y., Ruhiyat, Y., \& Nulhakim, L. (2020). Pengembangan Media Video Berbasis Powtoon pada Mata Pelajaran IPA di Kelas V. Jurnal Pendidikan Sains Indonesia, $\quad 8(2), \quad$ 269-279. DOI: https://doi.org/10.24815/jpsi.v8i2.16 835.

Zahro, R., \& Astono, J. (2017). Pengembangan Media Pembelajaran Majalah Fisika untuk Meningkatkan Motivasi dan Prestasi Belajar Fisika Peserta Didik SMA N 1 Pleret. Jurnal Pendidikan Fisika, 6(3), 215-223. Retrieved from http://journal.student.uny.ac.id. 